\title{
Expression of peroxiredoxin I regulated by gonadotropins in the rat ovary
}

\author{
Yu-Il Lee', Woo-Dae Kang ', Mi-Young Kim ${ }^{1}$, Moon-Kyoung Cho', Sang-Young Chun ${ }^{2}$ \\ 'Department of Obstetrics and Gynecology, ${ }^{2}$ Hormone Research Center, Chonnam National University Medical School, Gwangju, Korea
}

Objective: Peroxiredoxins (Prxs) play an important role in regulating cellular differentiation and proliferation in several types of mammalian cells. This report examined the expression of Prx isotype I in the rat ovary after hormone treatment.

Methods: Immature rats were injected with $10 \mathrm{IU}$ of pregnant mare's serum gonadotropin (PMSG) to induce the growth of multiple preovulatory follicles and $10 \mathrm{IU}$ of human chorionic gonadotropin (hCG) to induce ovulation. Immature rats were also treated with diethylstilbestrol (DES), an estrogen analogue, to induce the growth of multiple immature follicles. Northern blot analysis was performed to detect gene expression. Cell-type specific localization of Prx I mRNA were detected by in situ hybridization analysis.

Results: During follicle development, ovarian Prx I gene expression was detected in 3-day-old rats and had increased in 21-day-old rats. The levels of Prx I mRNA slightly declined one to two days following treatment with DES. A gradual increase in Prx I gene expression was observed in ovaries obtained from PMSG-treated immature rats. Furthermore, hCG treatment of PMSG-primed rats resulted in a gradual stimulation of Prx I mRNA levels by 24 hours (2.1-fold increase) following treatment, which remained high until 72 hours following treatment. In situ hybridization analysis revealed the expression of the Prx I gene in the granulosa cells of PMSG-primed ovaries and in the corpora lutea of ovaries stimulated with hCG for 72 hours.

Conclusion: These results demonstrate the gonadotropin and granulosa cell-specific stimulation of Prx I gene expression, suggesting its role as a local regulator of follicle development.

Keywords: Peroxiredoxins; Gene Expression; Ovarian Follicle; Gonadotropin Regulation; Rats, Sprague-Dawley

\section{Introduction}

Peroxiredoxins (Prxs) have recently been the subject of growing interest as a new family of thiol-specific antioxidant proteins [1]. These agents have been shown to play a critical role in peroxide detoxification by using reducing equivalents provided through the thioredoxin system but not from glutaredoxin [2,3]. They exist in multiple isoforms $[4,5]$ and catalyze the reduction of a broad range of different peroxides, including $\mathrm{H}_{2} \mathrm{O}_{2}$, alkyl hydroperoxides and peroxynitrite. The existence of different members of the Prx family has already been ob-

Received: Sep 2, 2010 · Revised: Oct 19, 2010 · Accepted: Oct 26, 2010 Corresponding author:Yu-II Lee

Department of Obstetrics and Gynecology, Chonnam National University Medical School, Hak 1-dong, Dong-gu, Gwangju 501-757, Korea Tel:+82-62-220-6371 Fax:+82-62-227-1637 E-mail: leeyi@chonnam.ac.kr

This is an Open Access article distributed under the terms of the Creative Commons Attribution Non-Commercial License (http://creativecommons.org/licenses/by-nc/3.0/) which permits unrestricted non-commercial use, distribution, and reproduction in any medium, provided the original work is properly cited. served in a variety of organisms, ranging from archaea to mammals [6]. The mammalian peroxiredoxin family consists of six proteins ( $P r x$ $\mathrm{I}-\mathrm{VI}$ ) expressed as unique gene products, with the capability of reducing hydrogen peroxide, lipid hydroperoxides, and peroxynitrite [7-10]. Prx I-IV are categorized as typical 2-Cys peroxiredoxins, distinct from the atypical 2-Cys (Prx V) and 1-Cys peroxiredoxin (Prx VI). Prx I-IV are members of a family containing a cysteine (Cys) on both the $\mathrm{N}$ - and C-terminal and form a homodimer with a head-to-tail type association [2]. Prx V, a monomeric form, also contains two Cys; this protein is the most recently discovered Prx from a mammalian system [11]. Prx $V$ is known to regulate apoptosis by inhibiting the $\mathrm{p} 53$-induced reactive oxygen species (ROS) formation [12]. Prx VI (1-Cys) contains only one Cys residue in the catalytic site and functions as a monomer [2]. Among these Prxs, Prx I is a basic ( $\mathrm{pH}$ 8.3) 22-kDa protein localized to the cytosol. Prx I is upregulated in a variety of cell types following exposure to oxidative stress. Upregulation of $\mathrm{Prx} I$ in response to $\mathrm{H}_{2} \mathrm{O}_{2}$ was first demonstrated in mouse peritoneal macrophages 
[13] and in cultured vascular smooth muscle cells following exposure to oxidized low-density lipoprotein [14].

In the ovary, regression of the corpus luteum is an example of degeneration of cellular function. Luteinizing hormone $(\mathrm{LH})$ causes depletion of ascorbic acid in the corpus luteum. Furthermore, reactive oxygen species have been shown to play a role in the regression of the corpus luteum [15]. However, the expression of Prx I in the ovary has not been reported. In the present study, therefore, the expression of Prx I was examined in the rat ovary.

\section{Methods}

\section{Animals}

Immature female rats of the Sprague-Dawley strain were purchased from Daehan Laboratories (Eumsung, Korea). They were housed in groups in a room with a controlled temperature and photoperiod (10-hours dark, 14-hours light, with lights on from 0600-2000 hours). The animals had access to food and water ad libitum. The animals, ranging in age from 3-21 days, were killed by cervical dislocation, and the ovaries were removed for RNA analysis. Ovaries were also collected from immature (26-day-old) rats at various times after treatment with 10 IU pregnant mare's serum gonadotropin (PMSG) (Sigma Chemical Co., St. Louis, MO, USA) to induce multiple follicle growth. To obtain immature growing granulosa cells for the proliferation assay, rats were treated with diethylstilbestrol (DES) (Sigma Chemical Co.) at 22 days of age. Some rats received a single intraperitoneal injection of 10 IU human chorionic gonadotropin (hCG) (Sigma Chemical Co.) to induce ovulation, and ovaries were obtained at different time intervals for northern blot and in situ hybridization analysis. Three to four ovarian samples obtained from different animals were included in the analysis. All animal handling and procedures were approved by the Institutional Animal Care and Use Committee of Chonnam National University.

\section{PCR cloning of rat Prx I}

Total RNA from the rat brain, testis, and lung was isolated using Trireagent solution. Five micrograms of total RNA were reverse transcribed using the Superscript Preamplification System (Gibco, Gaithersburg, MD, USA) according to the instruction manual. One microgram of reverse transcribed cDNA and $100 \mathrm{pM}$ of primer (Prx I's antisense, $5^{\prime}$-GAG TTT CTT AAA TTC TTC TGC TCT A-3' and sense, $5^{\prime}$-CTT CAG GAA ATG CAA AAA TTG GGC AT-3') was added in a final volume of $100 \mu \mathrm{L}$ containing $250 \mu \mathrm{M}$ each deoxynucleotide triphosphates, 2 $\mathrm{mM} \mathrm{MgCl} 2$, and $0.2 \mathrm{U}$ Taq polymerase. PCR was performed for $30 \mathrm{cy}$ cles with denaturing at $94^{\circ} \mathrm{C}$ for 1 minute, annealing at $65^{\circ} \mathrm{C}$ for 1.5 minutes, and elongation at $72^{\circ} \mathrm{C}$ for 1 minute. PCR products of the expected size (Prxl; 203 bp) were subcloned into pGEM-T Easy Vector
(Promega Co., Madison, WI, USA), and sequenced using T7 and T3 primers with automatic DNA sequencer (Perkin-Elmer, Foster City, (A, USA).

\section{Northern blot analysis}

Total RNA from ovaries was isolated using Tri-reagent solution (Molecular Research Center Inc., Cincinnati, OH, USA). Twenty micrograms of total RNA were fractionated by electrophoresis on a $1 \%$ agarose gel containing formaldehyde, and transferred to nylon membranes by capillary blotting with $10 \times$ sodium citrate-sodium chloride (SSC). After UV cross-linking and prehybridization, membranes were hybridized overnight at $42^{\circ} \mathrm{C}$ in solution containing $50 \%$ formaldehyde, $5 \times$ SSC, $1 \mathrm{mM}$ EDTA, $250 \mu \mathrm{g} / \mathrm{mL}$ denatured salmon sperm DNA, and a total of $2-4 \times 10^{6} \mathrm{cpm}$ of $\mathrm{a}^{32}$ P-labeled rat Prx I cDNA probes. After hybridization, membranes were washed twice for 5 minutes at room temperature in $2 \times \mathrm{SSC}$ and $0.1 \%$ SDS, followed by 1 hour at $65^{\circ} \mathrm{C}$ in $0.5 \times$ SSC and $0.1 \%$ SDS. Membranes were then exposed using Kodak RX films (Eastman Kodak Co., Rochester, NY, USA) for 1-4 days at $-80^{\circ} \mathrm{C}$.

\section{In situ hybridization analysis}

Rat ovaries were fixed at $4^{\circ} \mathrm{C}$ for 6 hours in $4 \%$ paraformaldehyde in phosphate-buffered saline (PBS), followed by immersion in $0.5 \mathrm{M} \mathrm{su}$ crose in PBS overnight. Cryostat sections ( $14 \mu \mathrm{m}$ thick) were mounted on poly-L-lysine (Sigma Chemical Co.) coated microscope slides, fixed in $4 \%$ paraformaldehyde in PBS, and stored at $-70^{\circ} \mathrm{C}$ until analyzed. The hybridization procedure was essentially the same as previously described [16]. In brief, sections were pretreated serially with $0.2 \mathrm{M} \mathrm{HCl}, 2 \times \mathrm{SSC}$, pronase $\mathrm{E}(0.125 \mathrm{mg} / \mathrm{mL}), 4 \%$ paraformaldehyde, and acetic anhydride in triethanolamine. Hybridization was carried out at $52-55^{\circ} \mathrm{C}$ overnight in the mixture containing ${ }^{35} \mathrm{~S}$-labeled rat Prx I cRNA probe $\left(10^{8} \mathrm{cpm} / \mathrm{mL}\right), 50 \%$ formamide, $0.3 \mathrm{M} \mathrm{NaCl}, 10 \mathrm{mM}$ TrisHCl, 5 mM EDTA, $1 \times$ Denhardt's solution, $10 \%$ dextran sulfate, $1 \mathrm{mg} /$ $\mathrm{mL}$ carrier transfer RNA, and $10 \mathrm{mM}$ dithiothreitol. Post-hybridization washing was performed under stringent conditions that included ribonuclease $A\left(25 \mathrm{mg} / \mathrm{mL}\right.$ ) treatment at $37^{\circ} \mathrm{C}$ for 30 minutes and a final stringency of $0.1 \times$ SSC. Slides were dipped into NTB-2 emulsion (Eastman Kodak $\mathrm{Co}_{0}$ ) and exposed at $4^{\circ} \mathrm{C}$ until being developed after 3 weeks. The slides were stained with hematoxylin and eosin and examined under a light microscope with bright- and dark-field illumination.

\section{Data analysis}

Statistical analyses of data in graphs were carried out by one-way ANOVA followed by Dunnett's test. A Student's $t$-test was performed to compare the two groups. A value of $p<0.05$ was considered significant. 


\section{Results}

\section{Levels of Prx I mRNAs during development}

The developmental changes in Prx I mRNA levels in the ovary were determined by a northern blot analysis. As shown in Figure $1 \mathrm{~A}$, the levels of $0.8 \mathrm{~Kb}$ Prx I transcripts were increased during development. The levels of ovarian Prx I transcript were three times higher in 21-dayold rats and two times higher in 15-day-old rats than those in 3-dayold or 6-day-old rats $(p<0.05)$ (Figure 1B).

\section{Regulation of Prx I expression by estrogen}

To study the effect of estrogen on Prx I expression in vivo, total RNA extracted from ovaries at different days after implantation of capsules containing diethylstilbestrol (DES) was analyzed by northern blotting. The levels of Prx I mRNA slightly, but not significantly, declined 1-2 days after DES treatment (Figure 2).

\section{Gonadotropin regulation of Prx I mRNA levels}

To examine gonadotropin regulation of Prx I mRNA levels in the ovary, total RNA extracted from ovaries at different times after gonadotropin treatments was analyzed by northern blotting. As shown in Figure 3A, PMSG treatment of 26-day-old immature rats caused an increase in ovarian expression of the Prx I gene. Prx I expression was markedly increased in ovaries treated with PMSG for 48 hours (twofold increase; $p<0.05$ ) (Figure 3B). The hypothalamus used as a positive control also expressed the Prx I gene. Furthermore, treatment
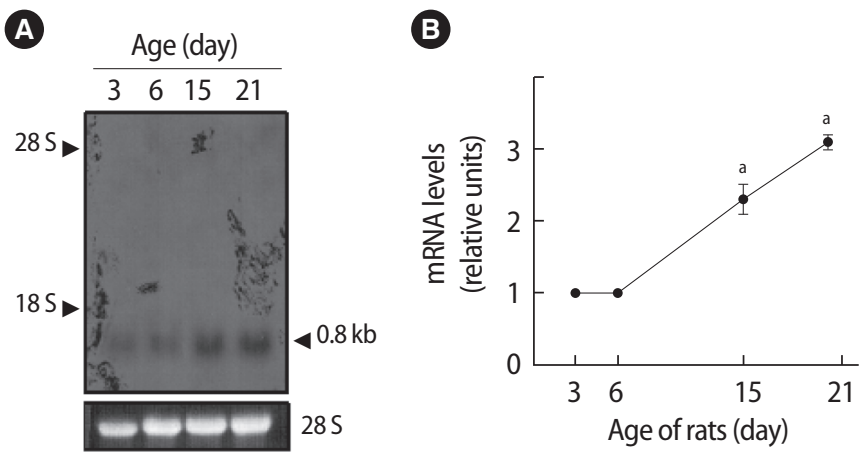

Figure 1. Developmental expression of Peroxiredoxin (Prx) I mRNAs in immature rat ovaries. (A) Aliquots of total RNA $(20 \mu \mathrm{g})$ isolated from ovaries on the indicated postnatal days were assayed for Prx mRNA levels by northern blotting using a rat Prx cDNA probe. The estimated size $(0.8 \mathrm{~kb})$ of the Prx I transcript is indicated. The expression of $28 \mathrm{~S}$ ribosomal RNA was used as an internal standard. (B) Quantitative estimation of ovarian Prx I mRNA levels during development. The 0.8 kb Prx I transcript was quantified using a phosphorimager and normalized for $28 \mathrm{~S}$ ribosomal RNA levels in each sample. Results are expressed relative to ovarian Prx I mRNA levels found at 3 days of age. Each data point represents the mean \pm SE from four independently performed experiments. ${ }^{\mathrm{a}} p<0.05$ vs. day 3 . with hCG of PMSG-primed rats resulted in the stimulation of Prx I mRNAs within 24 hours $(p<0.05)$ (Figure 4A). High levels remained until 72 hours post-hCG treatment, which corresponds to the period
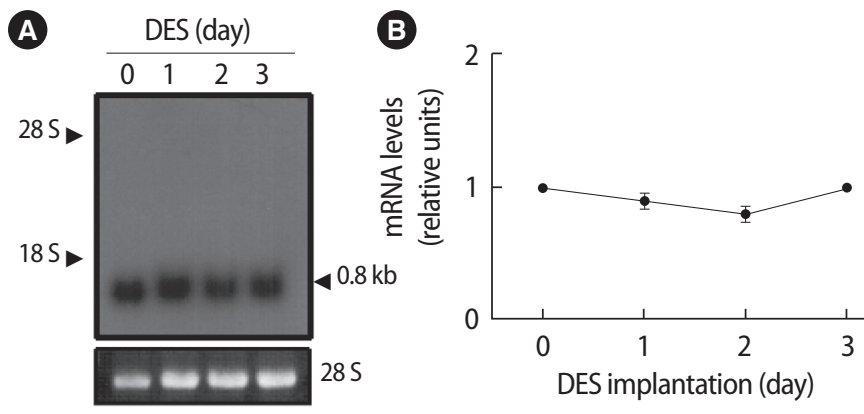

Figure 2. Expression of Prx I mRNA in ovaries of diethylstilbestrol (DES)-treated immature rats. (A) Ovarian total RNA was extracted at the indicated time interval after DES implantation. Aliquots of total RNA $(20 \mu \mathrm{v})$ isolated from ovaries on the indicated postnatal days were assayed for Peroxiredoxin (Prx) I mRNA levels by northern blotting using a rat Prx cDNA probe. The estimated size $(0.8 \mathrm{~kb})$ of the Prx I transcript is indicated. The expression of $28 \mathrm{~S}$ ribosomal RNA was used as an internal standard. (B) Quantitative estimation of ovarian Prx I mRNA levels during development. The 0.8 kb Prx I transcript was quantified using a phosphorimager and normalized for $28 \mathrm{~S}$ ribosomal RNA levels in each sample. Results are expressed relative to ovarian Prx I mRNA levels found at 0 days of age. Each data point represents the mean $\pm S E$ from four independently performed experiments.
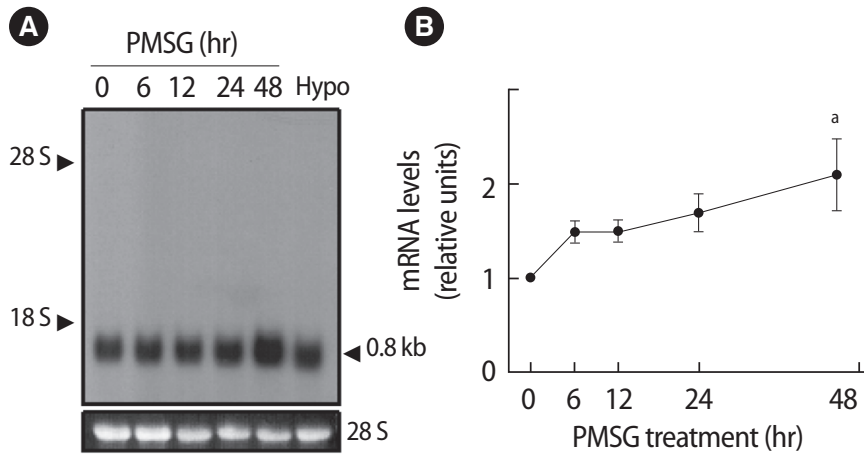

Figure 3. Changes in Peroxiredoxin (Prx) I mRNA levels in ovaries of pregnant mare's serum gonadotropin (PMSG)-treated immature rats. (A) Aliquots of total RNA $(20 \mu \mathrm{A})$ isolated from ovaries at the indicated time intervals after PMSG stimulation were assayed for Prx I mRNA levels by northern blotting using a rat Prx cDNA probe. The estimated size $(0.8 \mathrm{~kb})$ of the Prx transcript is indicated. The expression of $28 \mathrm{~S}$ ribosomal RNA was used as an internal standard. Hypo, hypothalamus. (B) Quantitative estimation of ovarian Prx mRNA levels during gonadotropin stimulation. The $0.8 \mathrm{~kb}$ Prx I transcript was quantified using a phosphorimager and normalized for $28 \mathrm{~S}$ ribosomal RNA levels in each sample. Results are expressed relative to the ovarian Prx I mRNA levels found at 0 hour after PMSG treatment for PMSG-treated rat ovaries. Each data point represents the mean $\pm S E$ from three to four independently performed experiments. ${ }^{\mathrm{a}} p<0.05 \mathrm{vs}$. PMSG 0 hour. 
A

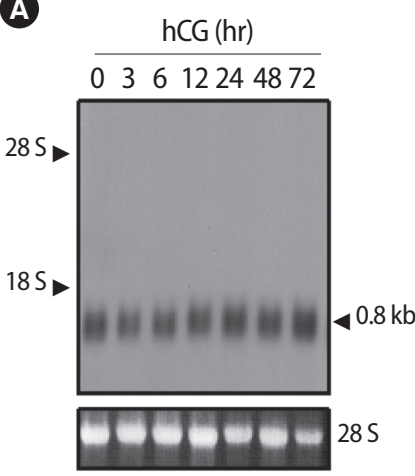

B

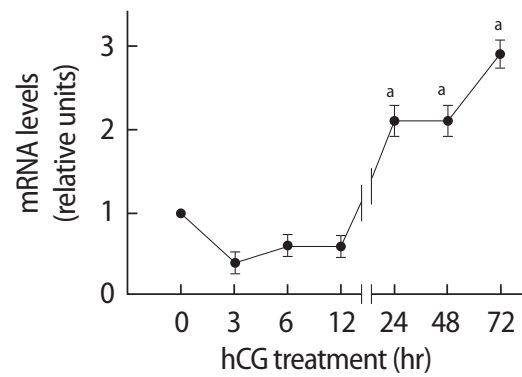

Figure 4. Changes in Peroxiredoxin (Prx) I mRNA levels in ovaries of pregnant mare's serum gonadotropin (PMSG)/hCGtreated immature rats. (A) Aliquots of total RNA $(20 \mu \mathrm{A})$ isolated from ovaries at the indicated time intervals after PMSG/ hCG stimulation were assayed for Prx I mRNA levels by northern blotting using a rat Prx CDNA probe. The estimated size $(0.8 \mathrm{~kb})$ of Prx transcript is indicated. The expression of $28 \mathrm{~S}$ ribosomal RNA was used as an internal standard. (B) Quantitative estimation of ovarian Prx I mRNA levels during gonadotropin stimulation. The $0.8 \mathrm{~kb} \operatorname{Prx}$ I transcript was quantified using a phosphorimager and normalized for $28 \mathrm{~S}$ ribosomal RNA levels in each sample. Results are expressed relative to the ovarian Prx I mRNA levels found at 0 hour after hCG treatment for PMSG/hCG treated rat ovaries. Each data point represents the mean \pm SE from three to four independently performed experiments. ${ }^{a} p<0.05$ vs. hCG 0 hour.
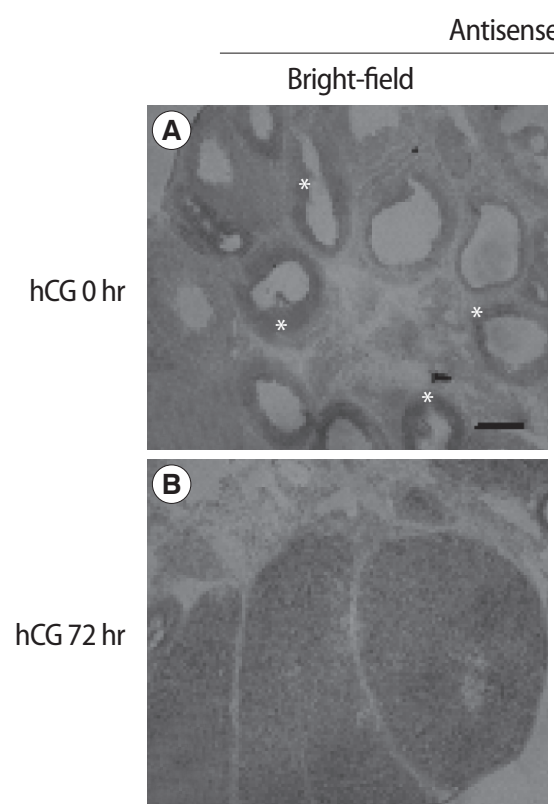
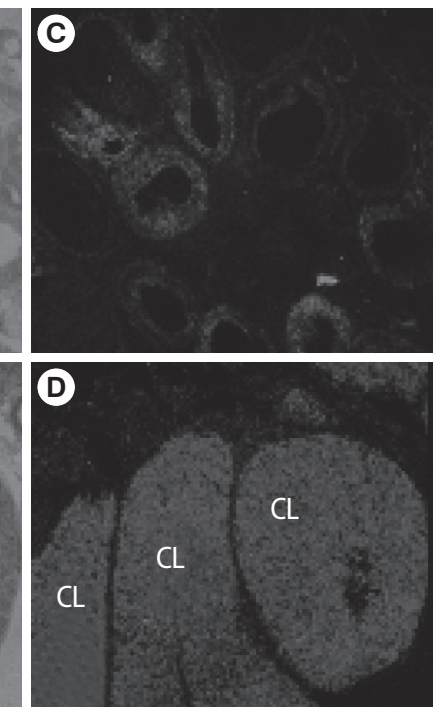

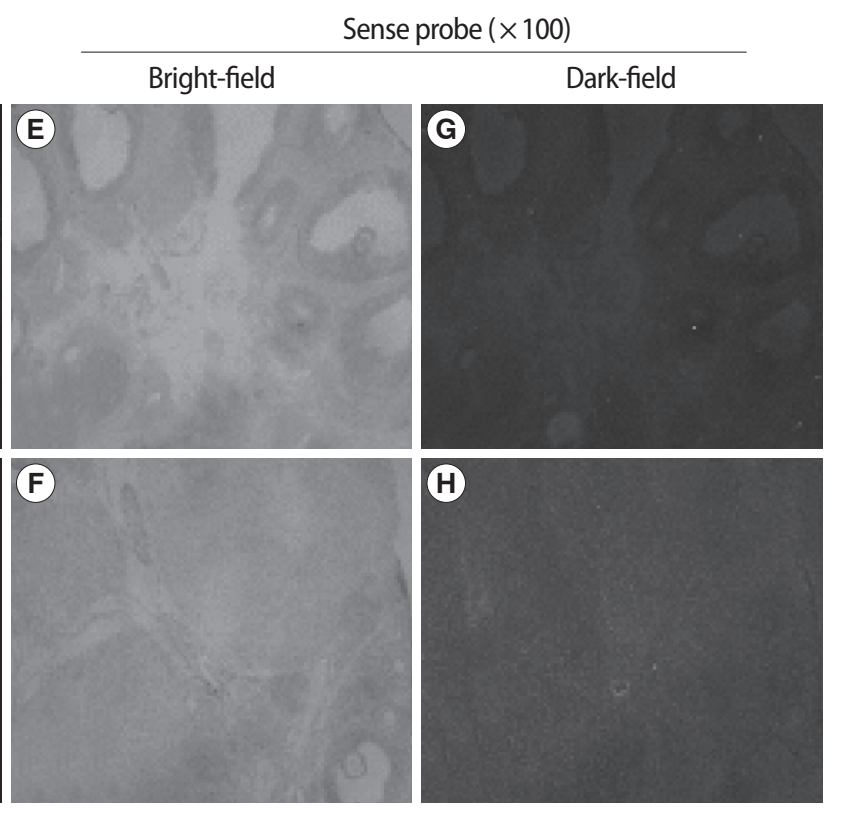

Figure 5. In situ localization of Peroxiredoxin (Prx) I mRNA in the rat ovary. Ovarian sections, obtained from immature rats treated with pregnant mare's serum gonadotropin/hCG, were hybridized with ${ }^{35}$ S-labeled rat Prx I cRNA probes. Photomicrographs were taken under bright (A, B, E, and F) and dark-field (C, D, G, and H) illumination. Adjacent sections, hybridized with the Prx I sense probe, showed only background signals (E, $\mathrm{F}, \mathrm{G}$, and H). CL, corpus luteum. ${ }^{*}$ Granulosa cells of preovulatory follicles. Bar $=100 \mu \mathrm{m}$.

of corpus luteum formation (Figure 4B). The levels of Prx I mRNA slightly declined 9-12 hours after stimulation.

\section{Localization of Prx I mRNAs in the rat ovary}

To determine the cell types expressing Prx I mRNA in hormonestimulated ovaries, antisense and sense cRNA probes for rat Prx I were generated for in situ hybridization analysis. In the ovaries of PMSGprimed immature rats, Prx I transcripts were detected in granulosa cells of preovulatory follicles (Figure 5A, 5C). In addition, in the ovaries of PMSG-primed immature rats followed by hCG stimulation for 72 hours, high levels of Prx I mRNA were expressed in corpus luteum cells (Figure 5B, 5D). No specific signal was detected in follicles hybridized with the sense probe (Figure $5 \mathrm{E}-5 \mathrm{H}$ ).

\section{Discussion}

The present study demonstrates that Prx I levels were regulated during follicle development in the rat ovary. Northern blot analysis, showing an increase in $0.8 \mathrm{~kb}$ Prx I transcription in the ovaries of 21-day-old rat, suggests the possible role of Prx in follicle growth. Furthermore, the expression of Prx isotypes was stimulated by gonadotropins during corpus luteum formation. 
Reactive oxygen species (ROS), the natural metabolites of intracellular oxygen, are constantly created and destroyed within the cell as a means of maintaining strict redox homeostasis. ROS such as hydrogen peroxide $\left(\mathrm{H}_{2} \mathrm{O}_{2}\right)$ and superoxide are created as a result of normal cellular signaling and metabolism [17], including oxidative phosphorylation [18]. Other causes of increased ROS levels include exposure to various drugs and hormones [19] and the overexpression of certain oncoproteins [20]. A group of enzymes that plays a major role in ROS regulation is the Prx family. Prxs reduce hydrogen peroxide and other peroxide substrates via conserved cysteine residues utilizing thiol-containing proteins, such as glutathione or thioredoxin, as electron donors $[2,21,22]$.

Intracellular ROS are a double-edged sword with both beneficial and deleterious consequences. On the one hand, ROS participate in normal cell signaling pathways [22-24]. For example, $\mathrm{H}_{2} \mathrm{O}_{2}$ oxidizes cysteine residues in protein-tyrosine phosphatases, which inhibits their function and leads to the upregulation of multiple tyrosine kinase-dependent signaling pathways in response to growth factors $[8,25]$. The best studied means for regulating ROS levels is via the Prxs. Each of the six mammalian Prxs has a specific tissue and subcellular distribution [2,21]. The most abundant and ubiquitous member of the Prxs, Prx I, is expressed at high levels in virtually every tissue, primarily as a nuclear ROS scavenger. Reactive oxygen species, including the superoxide anion and hydrogen peroxide, are generated in the ovary, but their origin is unknown [26]. Follicles and corpora lutea are subject to ischemic episodes, and leukocytic infiltration is evident at ovulation and leuteolysis [27]. Furthermore, xanthine oxidase in the presence of hypoxanthine evokes marked antigonadotropic and antisteroidogenic actions in ovarian cells [28]. Recent evidence links superoxide radical production to the regulation of corpus luteum function in the rat. In vivo treatment with prostaglandin $\mathrm{F}_{2} \mathrm{a}$ stimulates a burst of superoxide radicals shortly before progesterone secretion decreases [26], and generation of these radicals appears to be controlled by intracellular signaling pathways [29]. Therefore, the present observation, showing the stimulation of Prx I expression during corpus luteum formation, may implicate Prx in the initiation of corpus luteum formation by modulating superoxide radical production, and in turn, the generated superoxide radicals may alter progesterone production and thereby maintain the formation of the corpus luteum.

During follicle development, Prx I may play an important role in theca cell differentiation. It is known that ovarian follicular growth begins and proceeds to the late preantral stage independently of gonadotropin regulation [30]. Further development depends upon FSH acting upon its cognate receptor expressed by granulosa cells [31]. It has been suggested that insulin-like growth factor I, expressed in granulosa cells of healthy growing follicles, may promote follicle growth by augmenting granulosa cell FSH receptor responsiveness [32], and thereby amplifying $\mathrm{FSH}$-induced aromatase expression and $\mathrm{LH}$ receptor induction [33]. Similarly, activin has been shown to promote folliculogenesis during the preantral or early antral stages of growth of follicles by amplifying granulosa cell responsiveness to FSH [34]. Because the pattern of Prx expression seems to follow the spatial expression of P450scc [35] and steroidogenic acute regulatory protein [36] in cells engaged in steroidogenic activity, Prx I expression in the theca cells may be correlated with terminal commitment of cells for steroidogenic differentiation.

In summary, the present study demonstrates the presence and regulation of Prx I expression in the gonadotropin-treated ovaries. Stimulation of Prx I expression by gonadotropins indicates that Prx I may have a physiological function during ovarian follicle development. Particularly, the function of Prx I in corpus luteum formation remains to be established.

\section{Conflict of interest}

No potential conflict of interest relevant to this article was reported.

\section{References}

1. de Haan JB, Bladier C, Lotfi-Miri M, Taylor J, Hutchinson P, Crack PJ, et al. Fibroblasts derived from Gpx1 knockout mice display senescent-like features and are susceptible to $\mathrm{H}_{2} \mathrm{O}_{2}$-mediated cell death. Free Radic Biol Med 2004;36:53-64.

2. Fujii J, Ikeda Y. Advances in our understanding of peroxiredoxin, a multifunctional, mammalian redox protein. Redox Rep 2002;7: 123-30.

3. Das KC. Thioredoxin system in premature and newborn biology. Antioxid Redox Signal 2004;6:177-84.

4. Dietz KJ, Horling F, König J, Baier M. The function of the chloroplast 2-cysteine peroxiredoxin in peroxide detoxification and its regulation. J Exp Bot 2002;53:1321-9.

5. Rouhier N, Jacquot JP. Plant peroxiredoxins: alternative hydroperoxide scavenging enzymes. Photosynth Res 2002;74:259-68.

6. Bréhélin C, Meyer EH, de Souris JP, Bonnard G, Meyer Y. Resemblance and dissemblance of Arabidopsis type II peroxiredoxins: similar sequences for divergent gene expression, protein localization, and activity. Plant Physiol 2003;132:2045-57.

7. Ishii T, Kawane T, Taketani S, Bannai S. Inhibition of the thiol-specific antioxidant activity of rat liver MSP23 protein by hemin. Biochem Biophys Res Commun 1995;216:970-5.

8. Kang SW, Chae HZ, Seo MS, Kim K, Baines IC, Rhee SG. Mammalian peroxiredoxin isoforms can reduce hydrogen peroxide generated in response to growth factors and tumor necrosis factor- 
alpha. J Biol Chem 1998;273:6297-302.

9. Kim H, Lee TH, Park ES, Suh JM, Park SJ, Chung HK, et al. Role of peroxiredoxins in regulating intracellular hydrogen peroxide and hydrogen peroxide-induced apoptosis in thyroid cells. J Biol Chem 2000;275:18266-70.

10. Bryk R, Griffin P, Nathan C. Peroxynitrite reductase activity of bacterial peroxiredoxins. Nature 2000;407:211-5.

11. Seo MS, Kang SW, Kim K, Baines IC, Lee TH, Rhee SG. Identification of a new type of mammalian peroxiredoxin that forms an intramolecular disulfide as a reaction intermediate. J Biol Chem 2000;275:20346-54.

12. Zhou Y, Kok KH, Chun AC, Wong CM, Wu HW, Lin MC, et al. Mouse peroxiredoxin $\mathrm{V}$ is a thioredoxin peroxidase that inhibits p53-induced apoptosis. Biochem Biophys Res Commun 2000;268:921-7.

13. Ishii T, Yamada M, Sato H, Matsue M, Taketani S, Nakayama K, et al. Cloning and characterization of a 23-kDa stress-induced mouse peritoneal macrophage protein. J Biol Chem 1993;268: 18633-6.

14. Siow RC, Ishii T, Sato H, Taketani S, Leake DS, Sweiry JH, et al. Induction of the antioxidant stress proteins heme oxygenase-1 and MSP23 by stress agents and oxidised LDL in cultured vascular smooth muscle cells. FEBS Lett 1995;368:239-42.

15. Kovacic N, Parlow AF. Alterations in serum FSH-LH ratios in relation to the estrous cycle, pseudopregnancy, and gonadectomy in the mouse. Endocrinology 1972;91:910-5.

16. Lee J, Park HJ, Choi HS, Kwon HB, Arimura A, Lee BJ, et al. Gonadotropin stimulation of pituitary adenylate cyclase-activating polypeptide (PACAP) messenger ribonucleic acid in the rat ovary and the role of PACAP as a follicle survival factor. Endocrinology 1999;140:818-26.

17. Fang $Y Z$, Yang $S$, Wu G. Free radicals, antioxidants, and nutrition. Nutrition 2002;18:872-9.

18. Cao Z, Lindsay JG, Isaacs NW. Mitochondrial peroxiredoxins. Subcell Biochem 2007;44:295-315.

19. Klaunig JE, Xu Y, Isenberg JS, Bachowski S, Kolaja KL, Jiang J, et al. The role of oxidative stress in chemical carcinogenesis. Environ Health Perspect 1998;106 Suppl 1:289-95.

20. Lee AC, Fenster BE, Ito H, Takeda K, Bae NS, Hirai T, et al. Ras proteins induce senescence by altering the intracellular levels of reactive oxygen species. J Biol Chem 1999;274:7936-40.

21. Immenschuh S, Baumgart-Vogt E. Peroxiredoxins, oxidative stress, and cell proliferation. Antioxid Redox Signal 2005;7:768-77.

22. Rhee SG, Chae HZ, Kim K. Peroxiredoxins: a historical overview and speculative preview of novel mechanisms and emerging concepts in cell signaling. Free Radic Biol Med 2005;38:1543-52.
23. Wood ZA, Poole LB, Karplus PA. Peroxiredoxin evolution and the regulation of hydrogen peroxide signaling. Science 2003;300: 650-3.

24. Rhee SG. Cell signaling. $\mathrm{H} 2 \mathrm{O} 2$, a necessary evil for cell signaling. Science 2006;312:1882-3.

25. Jin DY, Chae HZ, Rhee SG, Jeang KT. Regulatory role for a novel human thioredoxin peroxidase in NF-kappaB activation. J Biol Chem 1997;272:30952-61.

26. Sawada M, Carlson JC. Rapid plasma membrane changes in superoxide radical formation, fluidity, and phospholipase $\mathrm{A} 2$ activity in the corpus luteum of the rat during induction of luteolysis. Endocrinology 1991;128:2992-8.

27. Kirsch TM, Friedman AC, Vogel RL, Flickinger GL. Macrophages in corpora lutea of mice: characterization and effects on steroid secretion. Biol Reprod 1981;25:629-38.

28. Gatzuli E, Aten RF, Behrman HR. Inhibition of gonadotropin action and progesterone synthesis by xanthine oxidase in rat luteal cells. Endocrinology 1991;128:2253-8.

29. Sawada M, Carlson JC. Studies on the mechanism controlling generation of superoxide radical in luteinized rat ovaries during regression. Endocrinology 1994;135:1645-50.

30. Kumar TR, Wang Y, Lu N, Matzuk MM. Follicle stimulating hormone is required for ovarian follicle maturation but not male fertility. Nat Genet 1997;15:201-4.

31. Uilenbroek JT, Richards JS. Ovarian follicular development during the rat estrous cycle: gonadotropin receptors and follicular responsiveness. Biol Reprod 1979;20:1159-65.

32. Zhou J, Kumar TR, Matzuk MM, Bondy C. Insulin-like growth factor I regulates gonadotropin responsiveness in the murine ovary. Mol Endocrinol 1997;11:1924-33.

33. Adashi EY, Resnick CE, Svoboda ME, Van Wyk JJ. Somatomedin-C enhances induction of luteinizing hormone receptors by folliclestimulating hormone in cultured rat granulosa cells. Endocrinology 1985; 116:2369-75.

34. Findlay JK. An update on the roles of inhibin, activin, and follistatin as local regulators of folliculogenesis. Biol Reprod 1993; 48:15-23.

35. Zlotkin T, Farkash Y, Orly J. Cell-specific expression of immunoreactive cholesterol side-chain cleavage cytochrome P-450 during follicular development in the rat ovary. Endocrinology 1986;119: 2809-20.

36. Ronen-Fuhrmann T, Timberg R, King SR, Hales KH, Hales DB, Stocco DM, et al. Spatio-temporal expression patterns of steroidogenic acute regulatory protein (StAR) during follicular development in the rat ovary. Endocrinology 1998;139:303-15. 